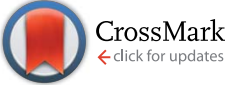

Cite this: RSC Adv., 2016, 6, 14140

\title{
Solid phase synthesis and RNA-binding activity of an arginine-containing nucleopeptide $\uparrow$
}

\author{
G. N. Roviello, ${ }^{\text {a }}$ C. Vicidomini, ${ }^{a}$ S. Di Gaetano, ${ }^{a}$ D. Capasso, ${ }^{\text {b D. Musumeciac }}$ \\ and V. Roviello
}

\begin{abstract}
Here we report the solid phase synthesis and characterization (LC-ESIMS, CD) of a cationic nucleobasecontaining $\alpha$-peptide, composed of both L-arginine residues and L-lysine-based nucleoamino acids sequentially present in the structure. The binding properties of this novel basic nucleopeptide towards nucleic acids were investigated by $C D$ spectroscopy which revealed the ability of the thymine-containing oligomer to bind both adenine-containing DNA $\left(\mathrm{dA}_{12}\right)$ and RNA (poly rA) molecules inducing high conformational variations in the nucleic acid structures. Moreover, the artificial oligonucleotide inhibited the enzymatic activity of HIV reverse transcriptase, opening the door to the exploitation of novel antiviral strategies inspired to this molecular tool.
\end{abstract}

Received 3rd December 2015 Accepted 15th January 2016

DOI: $10.1039 / c 5 r a 25809 j$

www.rsc.org/advances oligonucleotides with high sequence specificity ${ }^{14,15}$ With respect to other building blocks used for the realization of artificial nucleopeptides, diamino acids offer easy synthetic routes for decorating with nucleobases the main peptide backbone, realisable by simple oligomerization of the diamino acid units also in combination with other amino acid residues. ${ }^{16-18}$

Among the nucleic acids of biomedical relevance targeted by oligonucleotide mimics, poly $\mathrm{rA}$ tail has recently emerged as a good candidate in anticancer strategies. The poly rA tail, present in all eukaryotic mRNAs (as well as in some prokaryotes), is a polyadenylic chain of about 200 residues elongated by the enzyme poly(A) polymerase (PAP), able to confer stability to mRNAs, as well as to regulate the overall translation process. The poly rA tail length is influenced by the deposition onto mRNAs of nucleophosmin, a protein able to recognize Gquadruplex-forming nucleic acids, ${ }^{19}$ whose overexpression is associated with poor prognosis in cancer. ${ }^{20}$ The discovery that a specific neo-PAP is overexpressed in some human cancer cells suggests the importance of anticancer strategies having poly rA as a malignancy-specific target. ${ }^{21-23}$ Interesting interaction studies relative to the binding of synthetic compounds, both small organic molecules and nucleopeptides, with poly rA, are described in literature. ${ }^{23-28}$

Here, we investigated the binding properties towards poly $\mathrm{rA}$ RNA, as well as towards a complementary DNA, of a cationic nucleo- $\alpha$-peptide based on an arginine-lysine backbone carrying thymine nucleobases; nevertheless, the inhibitory activity respect to HIV reverse transcriptase (RT), the enzyme involved in the conversion of genomic viral RNA into proviral DNA, was explored, in analogy with our previous reports on both a basic oligopeptide containing diamino acid residues ${ }^{29}$ and an uncharged nucleo- $\alpha / \varepsilon$-peptide, ${ }^{30}$ which inhibited the RT in a dose-dependent manner.
${ }^{a}$ CNR, Istituto di Biostrutture e Bioimmagini -(Mezzacannone site and Headquarters), 80134 Napoli, Italy. E-mail: giovanni.roviello@cnr.it; Fax: +39-081-2534574; Tel: +39-081-2534585

${ }^{b}$ Università di Napoli "Federico II", Dipartimento di Farmacia, 80134 Napoli, Italy "Università di Napoli "Federico II", Dipartimento di Scienze Chimiche, 80126 Napoli, Italy

${ }^{d}$ Università di Napoli "Federico II", Dipartimento di Ingegneria Chimica, dei Materiali e della Produzione Industriale (DICMaPI), 80125 Napoli, Italy

$\dagger$ Electronic supplementary information (ESI) available. See DOI: $10.1039 / \mathrm{c} 5 \mathrm{ra} 25809 \mathrm{j}$ 


\section{Results and discussion}

\section{Solid phase synthesis of the cationic nucleopeptide}

Recently, we described the synthesis of a new thymine nucleoamino acid, suitably protected for solid phase peptide synthesis (Fmoc chemistry), and its oligomerization to a hexathymine nucleopeptide, obtained by alternating thyminebearing lysines and unmodified L-lysine units in the sequence. ${ }^{31}$ This basic nucleopeptide was found well soluble in aqueous solution, as well as able to bind both complementary DNA and RNA strands. ${ }^{26}$ In continuation with our previous studies, we present here the synthesis of another cationic nucleopeptide containing as repeating unit a dipeptide made of L-arginine and thyminyl-s-lysine. The synthesis of the oligomer was realised by coupling in alternate manner a commercially available monomer (i.e. Fmoc-L-Arg(Pbf)-OH) and the thyminebearing Fmoc-protected L-lysine, synthesised as previously described by us in literature. ${ }^{31}$ A dodecapeptide was assembled by solid phase peptide synthesis in analogy with previous reports $^{31,32}$ by using the above-mentioned monomers and PyBOP/DIEA in NMP as coupling system (overall yield $=75 \%$, based on Fmoc UV-measurements, Scheme 1). The obtained oligomer (1) was deprotected and cleaved from the solid support by acidic treatment and purified by RP-HPLC on a C-18 column with a linear gradient of $\mathrm{CH}_{3} \mathrm{CN}\left(0.1 \%\right.$ TFA) in $\mathrm{H}_{2} \mathrm{O}$ (0.1\% TFA).
LC-ESIMS characterization (positive ions) confirmed the identity of the nucleopeptide (Fig. S1 $\dagger$ ) which was obtained, after HPLC purification, in 55\% overall yield, as estimated by UV measurements at $260 \mathrm{~nm}$. This compound showed a good solubility in water and no detectable tendency to aggregate at the concentrations explored in this study.

\section{CD conformational studies}

The structural characteristics of nucleopeptide 1 were investigated by means of CD spectroscopy. First of all, we analysed the CD profile of the cationic oligomer in order to evaluate some pre-organization of the molecule in the adopted experimental conditions: no significant $\alpha$-helical contribution was detected in the CD spectrum of $\mathbf{1}$ (Fig. $\mathrm{S} 2 \dagger$ ).

After this first analysis, we studied the CD behaviour of the nucleopeptide by varying the temperature, and more in detail, we recorded different CD spectra for a $2 \mu \mathrm{M}$ solution of 1 in the 210-320 $\mathrm{nm}$ range at different temperatures: an overall decrease of the CD signal and particularly of the band at about $216 \mathrm{~nm}$ was observed upon increasing the temperature from 5 to $85{ }^{\circ} \mathrm{C}$ (Fig. 1). This behaviour can be ascribed to conformational changes that the nucleopeptide experiences intramolecularly, or to the perturbation of possible supramolecular assemblies given by multiple nucleopeptide units, whose super-structure could be subjected to modifications upon heating. However, these hypotheses need to be confirmed with further studies.

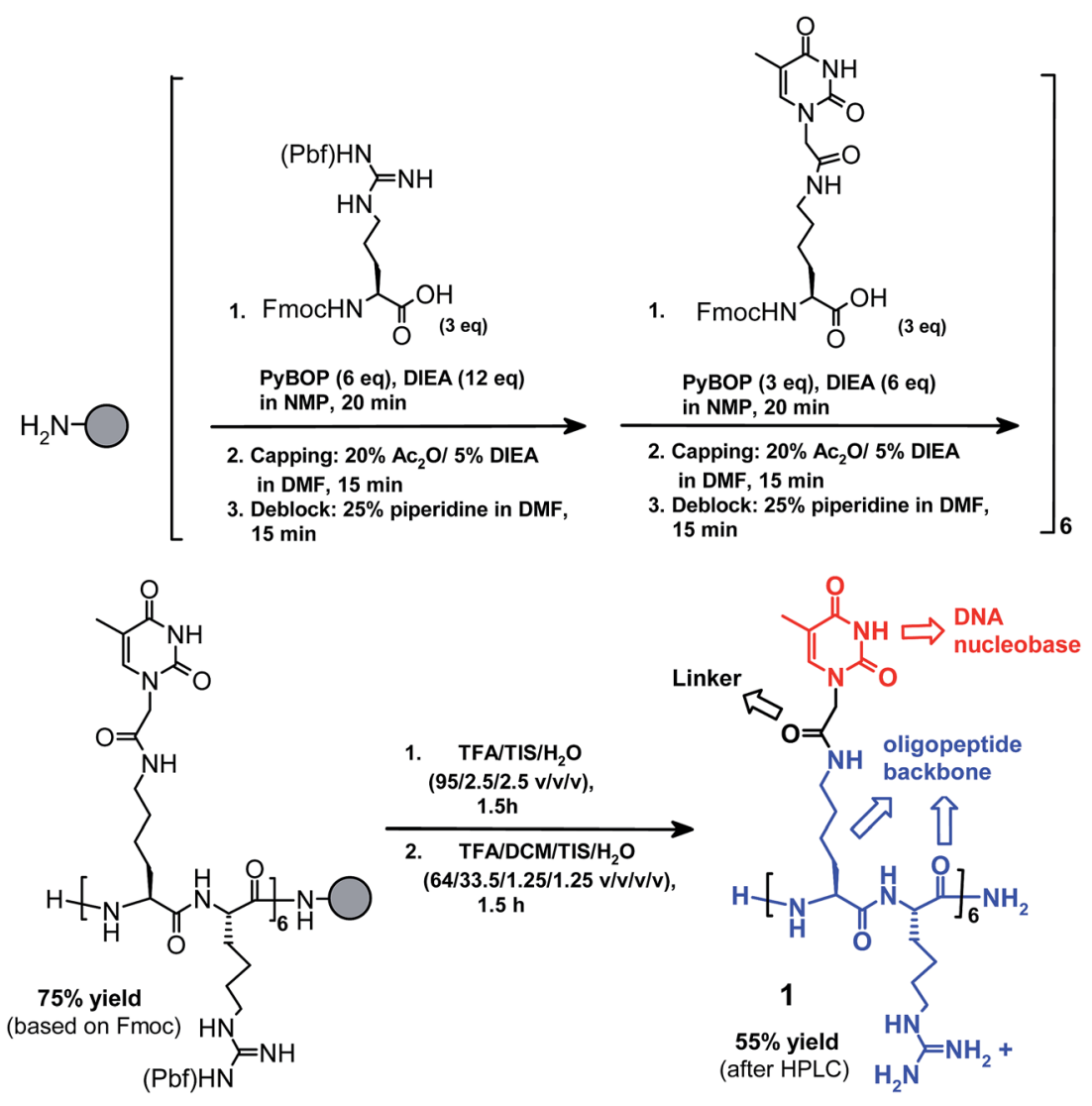

Scheme 1 Solid phase synthesis of oligomer 1. 

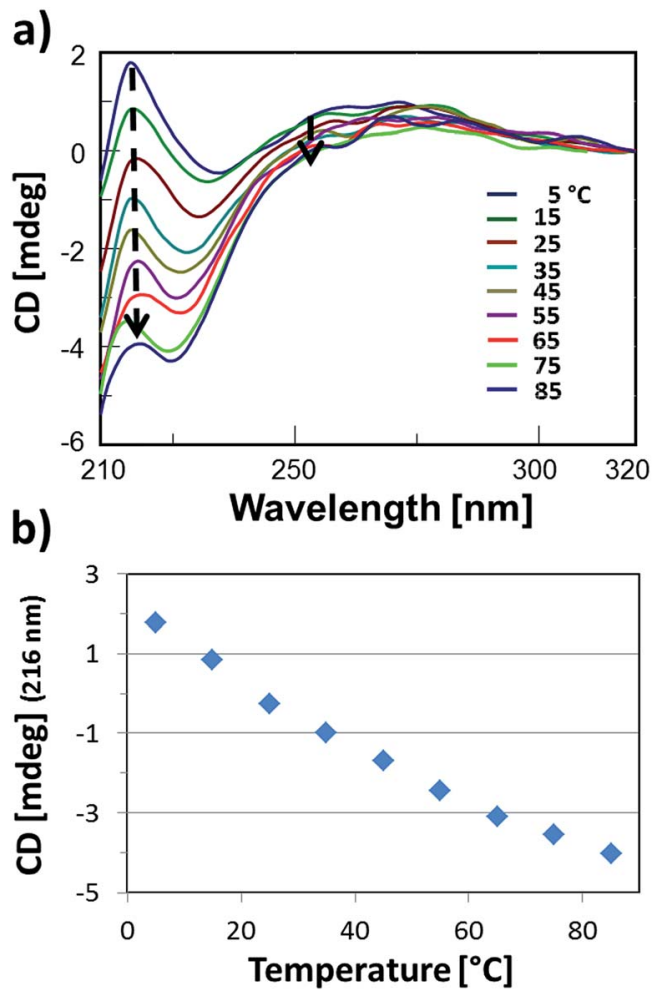

Fig. 1 (a) Overlapped CD spectra at various temperatures (from 5 to $85^{\circ} \mathrm{C}$ ) of nucleopeptide 1 at $2 \mu \mathrm{M}$ concentration in $5 \mathrm{mM}$ phosphate buffer ( $\mathrm{pH}$ 7.5); (b) CD signal values at $216 \mathrm{~nm}$ as a function of the temperature.

\section{CD binding studies with nucleic acids}

The first biological property of our artificial oligonucleotide which we were interested in investigating was its ability to bind nucleic acids. Since the sequence with which it was built up contains only thymine bases, we used for our experiments DNA and RNA molecules with homoadenine sequences. More in detail, a first $\mathrm{CD}$ binding assay was performed with a $\mathrm{dA}_{12}$ DNA by using a tandem cell: $16 \mathrm{nmol}$ in nucleobase (T) of nucleopeptide 1 and $8 \mathrm{nmol}$ in nucleobase (A) of $\mathrm{dA}_{12}$ DNA, both dissolved in $10 \mathrm{mM}$ phosphate buffer $(\mathrm{pH}=7.5)$, were introduced separately in the two reservoirs of a dual chamber quartz cell (tandem cell), and the sum CD spectrum was initially recorded at $5{ }^{\circ} \mathrm{C}$ (Fig. 2a, black line). The thymine-based oligomer gave a contribution to this CD spectrum very weak in comparison to the signal of the homoadenine DNA single strand. After mixing the solutions of the two components, another CD spectrum was recorded monitoring the stabilization of the signal (which occurred after about $20 \mathrm{~min}$ ): a significant difference between the sum and mixing CD spectra was observed in both shape and intensity of the spectroscopic profiles, revealing an interaction between the nucleopeptide and DNA with a remarkable structural reorganization (Fig. 2a, red line). In order to ascertain if this DNA/nucleopeptide binding was base-pairing-driven and not only due to possible electrostatic interactions, we performed an analogous experiment by using a $\mathrm{dT}_{12}$ DNA strand which was, thus, non-complementary to the homothymine nucleopeptide. Contrarily to the previous binding assay, upon mixing the solutions of 1 and $\mathrm{dT}_{12}$ we found only a variation of the intensity of the CD spectrum, probably attributable to the ionic interactions occurring between the negatively-charged DNA and the basic nucleopeptide, without any significant change in the profile of the spectrum (Fig. 2b). Instead, the differences observed between the sum and mixing $\mathrm{CD}$ spectra in the experiment with $\mathrm{dA}_{12}$, involving not only changes in signal intensities but also the appearance of new $\mathrm{CD}$ bands, accounted for the contribution of both electrostatic and nucleobase-pairing effects. These observations suggested that the artificial nucleopeptide interacted with the complementary nucleic acid via recognition between the complementary nucleobases, and not only through ionic interactions, which are however present as expected.

In order to further explore the interaction of the nucleopeptide with DNA, UV melting experiments on the $1 / \mathrm{dA}_{12}(2: 1$ in $\mathrm{T} / \mathrm{A}$ ratio) complex were performed. In the melting curve, reported in Fig. 3, two cooperative transitions with melting temperatures of about 34 and $72{ }^{\circ} \mathrm{C}$ were evidenced denoting the probable formation of a triplex structure containing $\mathrm{T} \cdot \mathrm{A} \times$ $\mathrm{T}$ triplets. A higher thermal stability with respect to a classical $\left(\mathrm{dT}_{6}\right)_{2} \mathrm{dA}_{12}$, but also $\left(\mathrm{dT}_{12}\right)_{2} \mathrm{dA}_{12}$, natural DNA triplex was observed.

Furthermore, the ability of the $t_{6}$-nucleopeptide to bind a complementary RNA was investigated by $\mathrm{CD}$ in analogy to the procedure employed in the case of DNA. In particular, we

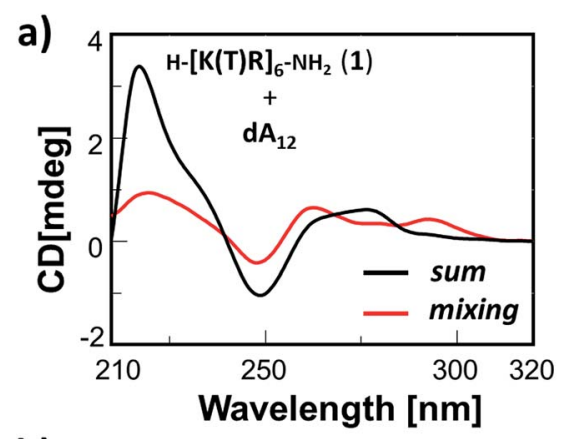

b)

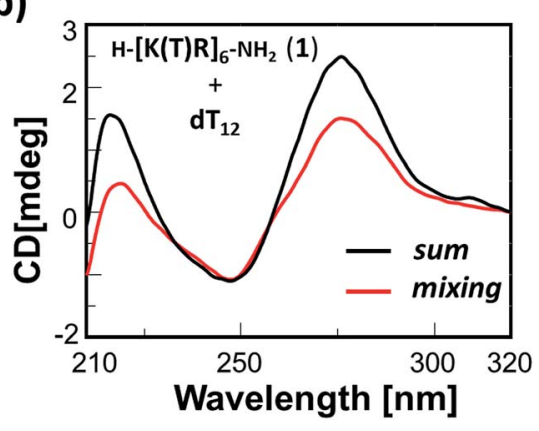

Fig. $2 C D$ binding studies of 1 with DNA in the tandem cell. (a) $t_{6}$ nucleopeptide ( $16 \mathrm{nmol}$ in $\mathrm{T})+\mathrm{dA}_{12}(8 \mathrm{nmol}$ in $\mathrm{A})$ in $10 \mathrm{mM}$ phosphate buffer ( $\mathrm{pH}=7.5,2 \mathrm{ml}$ overall volume) before (sum $\mathrm{CD}$ spectrum, black line) and after mixing (mixing CD spectrum, red); (b) $t_{6}$-nucleopeptide $(16 \mathrm{nmol}$ in $\mathrm{T})+\mathrm{dT}_{12}(8 \mathrm{nmol}$ in $\mathrm{T})$ in $10 \mathrm{mM}$ phosphate buffer $(\mathrm{pH}=7.5$, $2 \mathrm{ml}$ overall volume) before (sum CD spectrum, black line) and after mixing (mixing CD spectrum, red). 


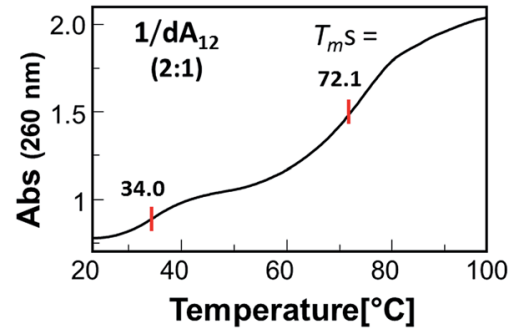

Fig. 3 UV-melting curve of the complex $1 / \mathrm{dA}_{12}(2: 1 \mathrm{in} \mathrm{T/A}$ ratio) in 10 $\mathrm{mM}$ phosphate buffer at $\mathrm{pH}=7.5$ (wavelength $=260 \mathrm{~nm}$; temperature increasing rate $=1{ }^{\circ} \mathrm{C} \mathrm{min}^{-1}$ ).

evaluated its possible interaction with poly rA, a RNA suggested as molecular target for anticancer approaches ${ }^{23}$ whose synthetic binders have gained a great importance in view of their potential employment in cancer therapy. In our poly rA-binding experiment, $16 \mathrm{nmol}$ in nucleobase $(\mathrm{T})$ of nucleopeptide and 8 $\mathrm{nmol}$ in nucleobase (A) of poly rA, both dissolved in $10 \mathrm{mM}$ phosphate buffer $\mathrm{pH}=7.5$, were introduced separately in the two cell chambers, and the sum CD spectrum was recorded at 5 ${ }^{\circ} \mathrm{C}$ (Fig. 4a, black line). After mixing the two solutions, the obtained CD spectrum (mixing, red line, Fig. 4a) showed a drastic change in both shape and intensity of the bands with respect to the sum spectrum revealing strong interactions of 1 with poly $\mathrm{rA}$ evidenced by significant variations of the RNA conformation after the nucleopeptide binding. On the other hand, by conducting the same binding experiment on solutions of $\mathbf{1}$ and poly rU (used as control), no relevant variation in the $\mathrm{CD}$ profile before and after mixing in the tandem cell was observed

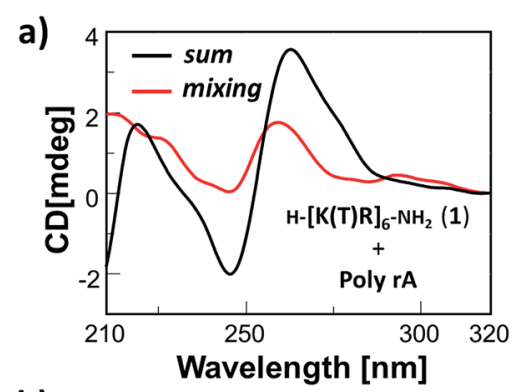

b)

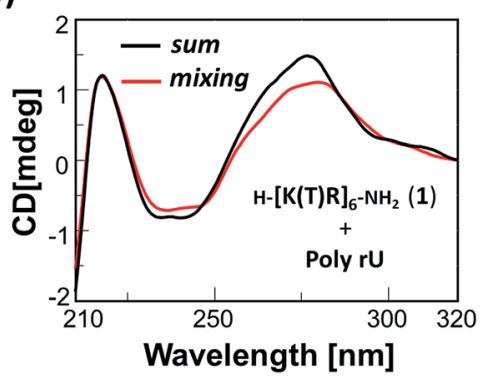

Fig. 4 CD binding studies of 1 with RNA in the tandem cell. (a) $t_{6}$ nucleopeptide ( $16 \mathrm{nmol}$ in T) + poly rA ( $8 \mathrm{nmol}$ in A) in $10 \mathrm{mM}$ phosphate buffer ( $\mathrm{pH}=7.5,2 \mathrm{ml}$ overall volume) before (sum $\mathrm{CD}$ spectrum, black line) and after mixing (mixing CD spectrum, red); (b) $t_{6}$-nucleopeptide $(16 \mathrm{nmol}$ in $\mathrm{T})+$ poly $\mathrm{rU}(8 \mathrm{nmol}$ in $\mathrm{U})$ in $10 \mathrm{mM}$ phosphate buffer ( $\mathrm{pH}=7.5,2 \mathrm{ml}$ overall volume) before (sum $\mathrm{CD}$ spectrum, black line) and after mixing (mixing CD spectrum, red).
(Fig. 4b), but only a slight reduction of the intensity of the bands, probably due to the electrostatic contribution to the interaction occurring between the anionic RNA and the cationic nucleopeptide, was found. This difference suggested also in this case that the interaction between the artificial nucleopeptide and the RNA is base-pairing-driven, and not only due to the electrostatic attraction between the strands.

It seems interesting that the nucleopeptide has a stronger effect in modifying the structure of the complementary RNA than DNA (compare the difference between the sum and mixing CD spectra of Fig. 2a and 4a), but the complexes formed with both DNA and RNA are structurally similar as evidenced by the corresponding CD spectra (mixing spectra) overlapped in Fig. 5 .

With the aim to obtain also quantitative information on the binding between the nucleopeptide and DNA or RNA, we performed CD titration experiments in which increasing amounts of oligomer 1 were added to solutions of the natural nucleic acids $\left(\mathrm{dA}_{12}\right.$ or poly $\mathrm{rA}$ ) (Fig. $6 \mathrm{a}$ and b). These experiments indicated in both cases the formation of multimeric complexes in which multiple nucleopeptide units bound the DNA or RNA targets. A certain stabilization of the CD signal was observed in correspondence of 2.5 (for the DNA) or 2 (for the RNA) equivalents in base of nucleopeptide (Fig. $6 \mathrm{c}$ and d) suggesting the formation of complexes with a T/A ratio of 2.5 or 2 in case of $\mathrm{dA}_{12}$ and poly rA, respectively. From the analysis of the data deriving from the titration experiments (see also Fig. S3 in the ESI materials $\dagger$ ), it was also evidenced that the structure of $\mathrm{dA}_{12}$ was perturbed starting from 1.5 eq. in $\mathrm{T}$ nucleobase of $\mathbf{1}$, whereas poly rA drastically changed already at 0.5 eq.

By comparing the nucleic acid-binding properties of nucleopeptide 1 with those of its analogue containing lysines in place of arginine residues, recently synthesized by us, ${ }^{26}$ we observed structural similarities in the complexes formed between the two homothymine nucleopeptides and poly $\mathrm{rA}$, whereas quite different structures of the complexes with $\mathrm{dA}_{12}$ were evidenced, as it can been denoted on the basis of the CD profiles. Moreover, a higher electrostatic contribution to the binding to $\mathrm{dA}_{12}$ was detected in case of nucleopeptide $\mathbf{1}$.

\section{HIV-RT inhibition studies}

The biological activity of $\mathbf{1}$ was then tested by an in vitro assay aimed to investigate its ability to interfere with HIV reverse-

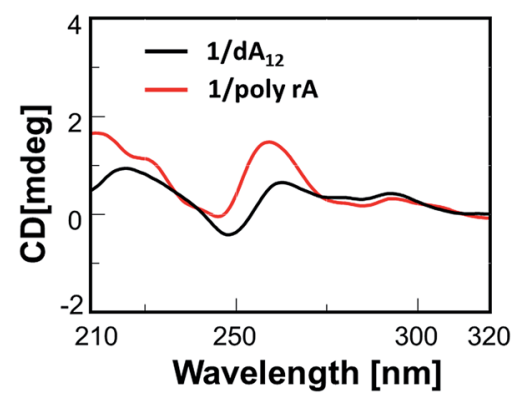

Fig. 5 Overlapped CD spectra of the complexes $1 / \mathrm{dA}_{12}$ (black line) and $1 /$ poly rA (red) in $10 \mathrm{mM}$ phosphate buffer at $\mathrm{pH}=7.5$. 
a)

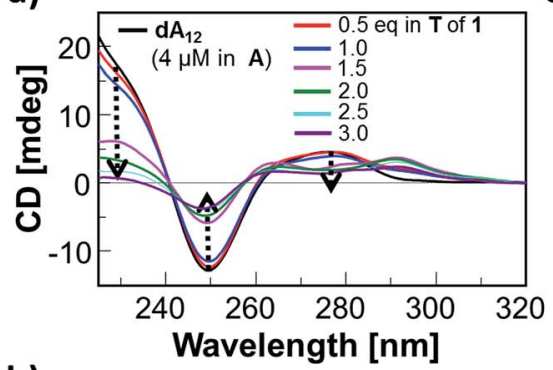

b)

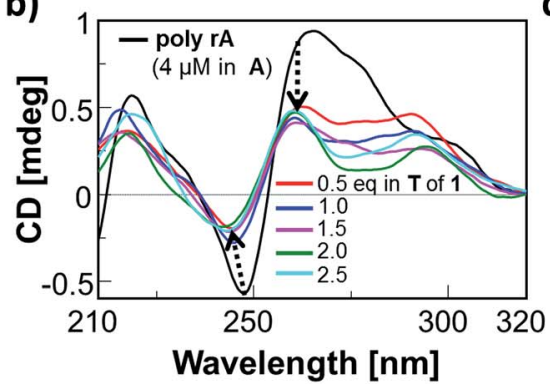

c)

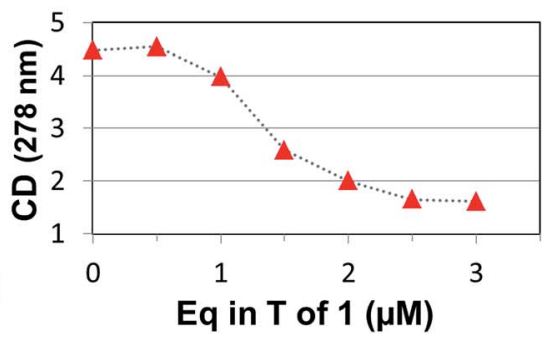

d)

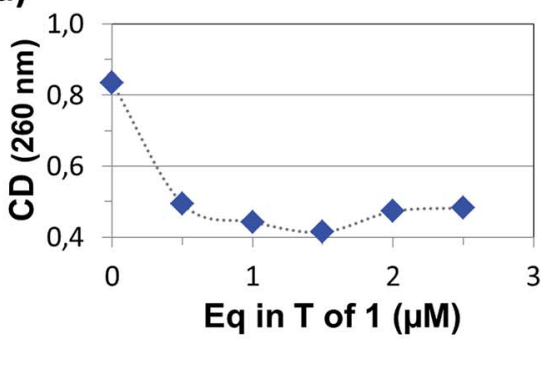

Fig. $6 \mathrm{CD}$ titration of $\mathrm{dA}_{12}$ (a) and poly $\mathrm{rA}$ (b) $(4 \mu \mathrm{M}$ in $\mathrm{A})$ with oligomer 1 at different equivalents of nucleobase, and corresponding variations of the CD-signal values at 278 ((c), for DNA) and $260 \mathrm{~nm}((\mathrm{~d})$, for RNA) as a function of the amount of nucleopeptide added.

transcription reaction using total RNA from HeLa cells and a $\mathrm{dT}_{12}$ primer for the viral enzyme. A PCR amplification experiment using specific primers for glyceraldehyde-3-phosphate dehydrogenase (gapdh) gene (a constitutive gene) was used to verify and quantify RT-inhibition degree. The results of these experiments revealed a reduced amount of transcription in the presence of a $1: 0.01,1: 0.06$ or $1: 0.25 \mathrm{~mol} \mathrm{~mol}^{-1}$ ratio of $\mathrm{dT}_{12} /$ nucleopeptide (Fig. 7).

In particular, when compared with the assay performed in the absence of 1 (lane 3, positive control, Fig. 7), the reduction of the transcription was quantified as about $60 \%$ in the presence of 3.8 pmol of 1 ( $1: 0.06$ ratio; lane 5 of Fig. 7$)$, reaching the complete inhibition with $15.1 \mathrm{pmol}$ (1: 0.25 ratio, lane 6).

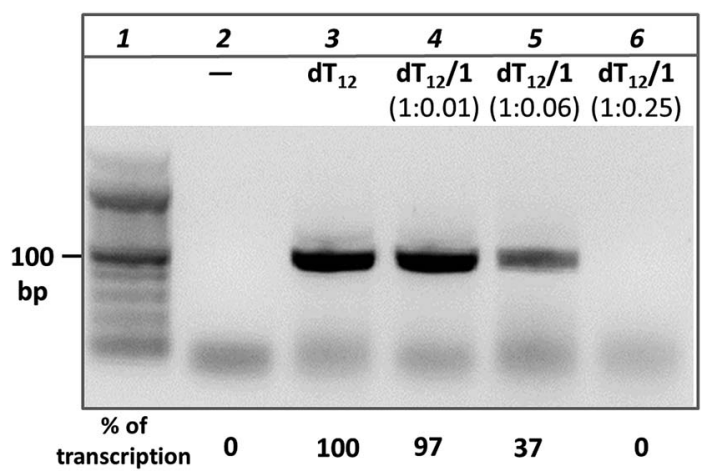

Fig. 7 Semiquantitative reverse transcription-PCR assay. Picture of the agarose gel, visualized by ethidium bromide staining, relative to the PCR products obtained by amplification of gapdh gene, following reverse transcription reaction performed (i) without primer (negative control, lane 2), (ii) with $\mathrm{dT}_{12}$ as primer for HIV-RT (positive control, lane 3) and (iii) with different amounts of $1(0.9 \mathrm{pmol}, 3.8 \mathrm{pmol}$ and 15.1 pmol, corresponding to a $1: 0.01,1: 0.06$ and $1: 0.25 \mathrm{dT}_{12} / 1$ ratio, respectively; lanes 4, 5 and 6 ).

\section{Enzymatic stability studies}

Finally, enzymatic stability of the nucleopeptide was studied by incubating $1(14 \mu \mathrm{M})$ in $94 \%$ fresh human serum at $37^{\circ} \mathrm{C}$ and analysing by RP-HPLC samples withdrawn from the reaction mixture at various times (Fig. 8).

Interestingly, serum stability assay denoted how the substitution of $-\mathrm{NH}_{3}{ }^{+}$moieties of the nucleopeptide presented in our recent work ${ }^{26}$ by guanidinium groups resulted in a lower enzymatic stability of oligomer 1 with respect to the previous nucleobase-bearing oligolysine strand. We hypothesise that guanidinium groups confer to the nucleopeptide a greater affinity towards the proteases and thus, provoke a faster

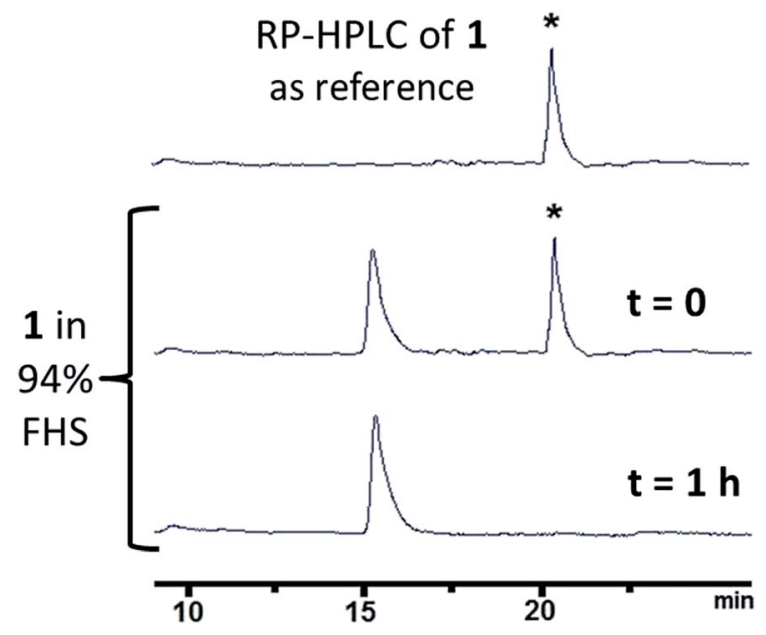

Fig. 8 HPLC profiles on a C-18 analytical column of 1 as reference (top) and of aliquots withdrawn from incubation of the nucleopeptide in $94 \%$ fresh human serum at $37{ }^{\circ} \mathrm{C}$ at different times (detection at $260 \mathrm{~nm})$ 
degradation of the compound that, anyway, showed a half-life comparable to that of small unmodified peptides. ${ }^{33}$

The here-presented nucleopeptide 1 resembles the wellknown peptide nucleic acids (PNAs) described for the first time by Nielsen. ${ }^{34}$ However, differently from PNAs, that have a pseudo-peptide backbone based on a repeated 2-aminoethylglycine moiety, our oligomer is based on an $\alpha$-peptide skeleton composed of natural amino acids. Some limits of classical PNAs, such as the scarce solubility in water, as well as the consequent tendency to aggregate, is overcome in our case thanks to the guanidinium moieties which confer to the overall structure a good water solubility.

\section{Experimental section}

\section{Abbreviations}

$\mathrm{Ac}_{2} \mathrm{O}$ (acetic anhydride); DCM (dichloromethane); DIEA ( $N, \mathrm{~N}-$ diisopropylethylamine); DMF ( $N, N$-dimethylformamide); NMP (4-methylpyrrolidone); PyBOP (benzotriazole-1-yl-oxy-trispyrrolidino-phosphonium hexafluorophosphate); RP (reverse phase); TFA (trifluoroacetic acid); TIS (triisopropylsilane).

\section{Chemicals and materials}

PyBOP and Fmoc-- $-\mathrm{Arg}(\mathrm{Pbf})-\mathrm{OH}$ were purchased from Novabiochem. Anhydroscan DMF and NMP were from LabScan. Piperidine was from Biosolve. Solvents for HPLC chromatography and $\mathrm{Ac}_{2} \mathrm{O}$ were from Reidel-de Haën. Poly rA, TFA and Rink-amide resin were Fluka. DCM, DIEA and TFA (for HPLC) were from Romil. TIS, human serum and poly rU were SigmaAldrich, whereas $\mathrm{dT}_{12}$ and $\mathrm{dA}_{12}$ DNA was Biomers.

\section{Apparatus}

HPLC analyses were performed on a Hewlett Packard/Agilent 1100 series, equipped with a diode array detector, by using a Phenomenex Jupiter C18 300 A column $(5 \mu \mathrm{m}, 4.6 \times 250 \mathrm{~mm})$ and a flow rate of $0.8 \mathrm{ml} \mathrm{min}^{-1}$. Elution was performed at $25^{\circ} \mathrm{C}$ (monitoring at $260 \mathrm{~nm}$ ) by building up a gradient starting with buffer A (0.1\% TFA in water) and applying buffer B $(0.1 \%$ TFA in acetonitrile). Circular dichroism (CD) spectra were recorded on a Jasco J-810 spectropolarimeter, whereas ultraviolet (UV) spectra were recorded on a UV-Vis Jasco model V-550 spectrophotometer equipped with a Peltier ETC-505T temperature controller using a $1 \mathrm{~cm}$ or a $(2 \times 0.4375) \mathrm{cm}$ Hellma quartz cells. Oligomer 1 were quantified measuring the UV absorbance $(\lambda=$ $260 \mathrm{~nm}$ ) of its solutions at $85{ }^{\circ} \mathrm{C}$, using the molar extinction coefficient calculated for the unstacked strand.

Crude sample containing the nucleopeptide was centrifuged for $4 \mathrm{~min}$ at $4000 \mathrm{rpm}$ ( $\mathrm{Z} 200 \mathrm{~A}$, Hermle). Products were analysed by LC-ESIMS, performed on an MSQ mass spectrometer (ThermoElectron, Milan, Italy) equipped with an ESI source operating at $3 \mathrm{kV}$ needle voltage and $320^{\circ} \mathrm{C}$, and with a complete Surveyor HPLC system, comprising an MS pump, an autosampler, and a PDA detector, by using a Phenomenex Jupiter C18 $300 \AA(5 \mu \mathrm{m}, 4.6 \times 150 \mathrm{~mm})$ column. Gradient elution was performed (monitoring at $260 \mathrm{~nm}$ ) by building up a gradient starting with buffer A ( $0.05 \%$ TFA in water) and applying buffer B (0.05\% TFA in acetonitrile) with a flow rate of $0.8 \mathrm{ml} \mathrm{min}^{-1}$.

Semi-preparative purification was performed by RP-HPLC on a Hewlett Packard/Agilent 1100 series, equipped with a diode array detector, by using a Phenomenex Jupiter C18 300 $\AA(10 \mu \mathrm{m}, 10 \times 250 \mathrm{~mm})$ column. Gradient elution was performed at $25{ }^{\circ} \mathrm{C}$ (monitoring at $260 \mathrm{~nm}$ ) by building up a gradient starting with buffer A $(0.1 \%$ TFA in water $)$ and applying buffer $\mathrm{B}(0.1 \%$ TFA in acetonitrile) with a flow rate of 4

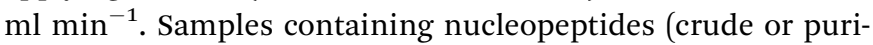
fied), were lyophilized in a FD4 Freeze Dryer (Heto Lab Equipment) for 16 hours.

\section{Solid phase synthesis of nucleopeptide 1}

Oligomer 1 was assembled on Rink-amide MBHA resin (0.50 mmol g $\left.{ }^{-1}, 8.0 \mathrm{mg}, 4 \mu \mathrm{mol}\right)$ using the synthetic strategy described in Scheme 1, starting from a nucleoamino acid monomer prepared as described in literature. ${ }^{31}$ More particularly, after Fmoc removal from the resin (by treatment with $25 \%$ piperidine in DMF for $30 \mathrm{~min}$ ), a mixture of (i) Fmoc-LLys( $\left.\mathrm{TCH}_{2} \mathrm{CO}\right)-\mathrm{OH}(120 \mu \mathrm{l}$ of a $0.1 \mathrm{M}$ solution in NMP, $12 \mu \mathrm{mol}$, 3 eq.), РyBOP ( $76 \mu \mathrm{l}$ of a $0.16 \mathrm{M}$ solution in NMP, $12 \mu \mathrm{mol}, 3$ eq.) and DIEA ( $4 \mu \mathrm{l}, 24 \mu \mathrm{mol}, 6$ eq.), or alternatively (ii) Fmoc-L$\operatorname{Arg}(\mathrm{Pbf})-\mathrm{OH}(182 \mu \mathrm{l}$ of a $0.13 \mathrm{M}$ solution in NMP, $24 \mu \mathrm{mol}, 6$ eq.) with PyBOP ( $152 \mu \mathrm{l}$ of a $0.16 \mathrm{M}$ solution in NMP, $24 \mu \mathrm{mol}, 6$ eq.) and DIEA ( $8 \mu \mathrm{l}, 48 \mu \mathrm{mol}, 12$ eq.) was introduced in the reactor and stirred at room temperature. After $20 \mathrm{~min}$ the liquid phase was removed from the resin which was washed with DMF, and, subsequently, unreacted amino groups were capped by treatment with $\mathrm{Ac}_{2} \mathrm{O}(20 \%) / \mathrm{DIEA}(5 \%)$ in DMF for 15 min. Fmoc group was then removed by treatment with $25 \%$ piperidine in DMF for $15 \mathrm{~min}$. The above-described procedure for the sequential introduction of the underivatized arginines and thyminil-lysines was repeated 12 times (overall yield based on Fmoc-UV-measurements was of $75 \%$ ). Deprotection and cleavage from the resin of the nucleopeptide was performed by treatment with $1.5 \mathrm{ml} \mathrm{TFA} / \mathrm{TIS} / \mathrm{H}_{2} \mathrm{O}(95 \% / 2.5 \% / 2.5 \%)$ for 90 min, followed by the addition of $1 \mathrm{ml}$ DCM and $0.5 \mathrm{ml}$ TFA leaving the reaction with stirring for further $90 \mathrm{~min}$. After removing the resin by filtration and reducing the amount of TFA/DCM on the filtrate by $\mathrm{N}_{2}$ stream, precipitation with cold diethyl ether, solubilisation in milliQ $\mathrm{H}_{2} \mathrm{O}$ and lyophilisation of the crude were performed. The nucleopeptide was then purified by RP-HPLC using a linear gradient of $10 \%$ (for $5 \mathrm{~min}$ ) to $30 \% \mathrm{~B}$ in A over $30 \mathrm{~min}: t_{\mathrm{R}}=20.0 \mathrm{~min}$. After lyophilisation, the purified product was dissolved in a known amount of milliQ water and quantified by UV measurements at $260 \mathrm{~nm}$ giving $2.2 \mu \mathrm{mol}$ of 1 (55\% yield); the compound was $\geq 95 \%$ pure by HPLC analysis. The epsilon value used for the quantification of the oligomer $\left(51600 \mathrm{M}^{-1} \mathrm{~cm}^{-1}\right)$ was calculated by the molar extinction coefficient of the thymine PNA monomer (8600 $\mathrm{M}^{-1} \mathrm{~cm}^{-1}$ ). ESIMS of 1 gave the following $\mathrm{m} / z$ values: 681.41 (found), 681.02 (expected for $\left[\mathrm{C}_{114} \mathrm{H}_{183} \mathrm{~N}_{49} \mathrm{O}_{30}+4 \mathrm{H}\right]^{4+}$ ); 907.41 (found), 907.69 (expected for $\left[\mathrm{C}_{114} \mathrm{H}_{183} \mathrm{~N}_{49} \mathrm{O}_{30}+3 \mathrm{H}\right]^{3+}$ ); 1361.07 (found), 1361.03 (expected for $\left[\mathrm{C}_{114} \mathrm{H}_{183} \mathrm{~N}_{49} \mathrm{O}_{30}+\right.$ $\left.2 \mathrm{H}]^{2+}\right)$. 


\section{CD studies}

CD spectra were recorded in the $210-320 \mathrm{~nm}$ wavelength range using a $(2 \times 0.4375) \mathrm{cm}$ Hellma dual-chamber quartz cell. CD spectra were obtained by using the following parameters: scan speed $50 \mathrm{~nm} \min ^{-1}$, data pitch $2 \mathrm{~nm}$, band width $2 \mathrm{~nm}$, response $4 \mathrm{~s}, 5$ accumulations.

\section{Cell culture}

HeLa cell lines (ATCC, USA) were grown in RPMI1640 medium supplemented with 10\% fetal bovine serum (FBS), 1\% glutamine, $100 \mathrm{U} \mathrm{ml}^{-1}$ penicillin and $100 \mu \mathrm{g} \mathrm{ml} \mathrm{m}^{-1}$ streptomycin (Euroclone, Italy) at $37{ }^{\circ} \mathrm{C}$ in humidified air with $5 \% \mathrm{CO}_{2}$.

\section{RT-PCR}

Total RNA was extracted from the cellular lysate by using Trireagent $^{\mathrm{TM}}$ (Sigma Aldrich, S. Luis, MO) following the manufacturer's instructions. Reverse transcription was performed using $0.5 \mu \mathrm{g}$ of total RNA, $1 \mathrm{U}$ of HIV-RT (Applied Biosystems, USA), $250 \mathrm{ng}$ of $\mathrm{dT}_{12}$ primer (Roche, Switzerland) in the presence of $0.9 \mathrm{pmol}, 3.8 \mathrm{pmol}$ and $15.1 \mathrm{pmol}$ of 1 , corresponding to a $1: 0.01,1: 0.06$ and $1: 0.25$ ratio respectively, in a volume of $20 \mu \mathrm{l}$. A pre-incubation of the RNA, 1 and the primer was performed for $3 \mathrm{~min}$ at $70{ }^{\circ} \mathrm{C}$ : then the mixture was placed at $4{ }^{\circ} \mathrm{C}$. After reverse transcription, performed at $42^{\circ} \mathrm{C}$ for $1 \mathrm{~h}$, the PCR amplification of GAPDH transcripts was carried out using the following primers: forward primer, 5'-ATGGGGAAGGT GAAGGTC-3', reverse primer $5^{\prime}$-GTCATGGATGACCTTGGC-3' (purchased by Sigma-Genosys Ltd) respectively. The PCR program was as follow: $\left(95^{\circ} \mathrm{C}, 5 \mathrm{~min}\right) \times 1$ cycle, $\left(95^{\circ} \mathrm{C}, 1 \mathrm{~min} ; 58\right.$ $\left.{ }^{\circ} \mathrm{C}, 1 \mathrm{~min} ; 72{ }^{\circ} \mathrm{C}, 1 \mathrm{~min}\right) \times 25$ cycles. PCR products were then analysed on $1 \%$ agarose gel with $1 \times$ TAE buffer and visualized by ethidium bromide staining. Gel images were captured by a ChemiDoc ${ }^{\mathrm{TM}}$ XRS and analysed by Quantity-One software (Biorad, Hercules, CA).

\section{Human serum stability assay}

The serum stability assay was performed following a procedure already reported by us in literature. ${ }^{35,36}$ HPLC analyses of the samples withdrawn from the incubation mixture of the peptide in fresh human serum at $37^{\circ} \mathrm{C}$ (detection at $260 \mathrm{~nm}$ ) were obtained on a Hewlett Packard/Agilent 1100 series, equipped with a diode array detector, by using a Phenomenex Jupiter C18 $300 \AA$ column $(5 \mu \mathrm{m}, 4.6 \times 250 \mathrm{~mm})$.

\section{Conclusions}

In conclusion, in this work we have described the synthesis and characterization of a novel nucleobase-modified peptide (1) containing six thymine-bearing lysines and six unmodified $\mathrm{L}^{-}$ arginine units. This basic nucleopeptide is well soluble in water and does not present any tendency to self-aggregate. Furthermore, CD characterization of 1 suggested that the homothymine oligomer does not undergo any helical preorganization under our experimental conditions. CD binding experiments showed that nucleopeptide $\mathbf{1}$ is able to interact with complementary DNA and RNA molecules in a $2: 1$ T/A stoichiometric ratio. As expected, the binding is due to both basepairing effects and electrostatic interactions occurring between the cationic guanidinium moieties of $\mathbf{1}$ and the negative phosphate groups present in the nucleic acid structures. By comparing the properties of nucleopeptide 1 with its analogue, recently synthesised by us, in which underivatized lysines residues replaced arginines, we observed the following features: (1) a reduced serum stability of $\mathbf{1}$ due probably to its greater affinity for proteases conferred by the guanidinium moieties, (2) different structures of the complexes of the two homothymine nucleopeptides with DNA $\mathrm{dA}_{12}$, with a higher degree of electrostatic contribution to the binding in the case of 1, (3) similar structures of the complexes of the two nucleopeptides with poly rA. Furthermore, in vitro biological assays evidenced that oligomer 1 acted as an inhibitor of HIV-RT, an enzyme which represents a fundamental drug target for anti-HIV therapies. Taken together, all these findings encourage further biological studies on the basic arginine-rich nucleopeptide, especially in the field of antiviral therapy. Thus, we plan (1) to radiolabel this nucleopeptide in view of future in vivo investigations based on the detection of the effects of this potential anti-HIV drug in animal models similarly to previous reports, ${ }^{37}$ (2) to assemble analogues of nucleopeptide 1 containing also the other nucleobases, especially guanines in order to explore also the possibility for this artificial oligomer to form G-quadruplex structures, very stable and efficient drug-candidates in many therapeutic strategies. ${ }^{38,39}$

\section{Acknowledgements}

We thank Prof. Antonio Roviello for his precious suggestions, and Mr Leopoldo Zona for his invaluable technical assistance. This work was supported by Consiglio Nazionale delle Ricerche (CNR) (research grant received under the bilateral CNR, Italy SRNSF, Georgia research Program 2014-2015) and Regione Campania (research grant received for the project "Nuovi sistemi nucleopeptidici per applicazioni diagnostiche" under the research program Legge Regionale n. 5 annualità 2007).

\section{References}

1 T. S. Zatsepin, E. A. Romanova, D. A. Stetsenko, M. J. Gait and T. S. Oretskaya, Synthesis of 2'-modified oligonucleotides containing aldehyde or ethylenediamine groups, Nucleosides, Nucleotides Nucleic Acids, 2003, 22, 1383-1385.

2 N. M. Bell and J. Micklefield, Chemical modification of oligonucleotides for therapeutic, bioanalytical and other applications, ChemBioChem, 2009, 10, 2691-2703.

3 D. D'Alonzo, A. Guaragna and G. Palumbo, Exploring the role of chirality in nucleic acid recognition, Chem. Biodiversity, 2011, 8, 373-413.

4 G. N. Roviello, E. Benedetti, C. Pedone and E. M. Bucci, Nucleobase-containing peptides: an overview of their characteristic features and applications, Amino Acids, 2010, 39, 45-57. 
5 G. N. Roviello, D. Musumeci, E. M. Bucci and C. Pedone, Evidences for supramolecular organization of nucleopeptides: synthesis, spectroscopic and biological studies of a novel dithymine $L$-serine tetrapeptide, Mol. BioSyst., 2011, 7, 1073-1080.

6 G. N. Roviello, G. Roviello, D. Musumeci, E. M. Bucci and C. Pedone, Dakin-West reaction on 1-thyminyl acetic acid for the synthesis of 1,3-bis(1-thyminyl)-2-propanone, a heteroaromatic compound with nucleopeptide-binding properties, Amino Acids, 2012, 43, 1615-1623.

7 C. Avitabile, L. Moggio, G. Malgieri, D. Capasso, S. Di Gaetano, M. Saviano, C. Pedone and A. Romanelli, $\gamma$ Sulphate PNA (PNA S): highly selective DNA binding molecule showing promising antigene activity, PLoS One, 2012, 7(5), e35774.

8 C. Avitabile, A. Cimmino and A. Romanelli, Oligonucleotide analogues as modulators of the expression and function of noncoding RNAs (ncRNAs): emerging therapeutics applications, J. Med. Chem., 2014, 57, 10220-10240.

9 A. Dragulescu-Andrasi, S. Rapireddy, B. He, G. Bhattacharya, J. J. Hyldig-Nielsen, G. Zon and D. H. Ly, Cell-permeable peptide nucleic acid designed to bind to the 5'untranslated region of E-cadherin transcript induces potent and sequence-specific antisense effects, J. Am. Chem. Soc., 2006, 128, 16104-16112.

10 A. R. Katritzky and T. Narindoshvili, Chiral peptide nucleic acid monomers (PNAM) with modified backbones, Org. Biomol. Chem., 2008, 6, 3171-3176.

11 A. Calabretta, T. Tedeschi, G. Di Cola, R. Corradini, S. Sforza and R. Marchelli, Arginine-based PNA microarrays for APOE genotyping, Mol. BioSyst., 2009, 5, 1323-1330.

12 A. C. van der Laan, I. van Amsterdam, G. I. Tesser, J. H. Van Boom and E. K. Yeheskiel, Synthesis of chirally pure ornithine-based PNA analogues, Nucleosides Nucleotides, 1998, 17, 219-231.

13 G. N. Roviello, D. Musumeci, A. De Cristofaro, D. Capasso, S. Di Gaetano, E. M. Bucci and C. Pedone, Alternate dabaegPNAs: synthesis, nucleic acid binding studies and biological activity, Mol. BioSyst., 2009, 6, 189-195.

14 T. Wada, N. Minamimoto, Y. Inaki and Y. Inoue, Peptide ribonucleic acids (PRNA). 2. A novel strategy for active control of DNA recognition through borate ester formation, J. Am. Chem. Soc., 2000, 122, 6900-6910.

15 N. Sawa, T. Wada and Y. Inoue, Synthesis and DNArecognition behavior of a novel peptide ribonucleic acid with a serine backbone (oxa-PRNA), Tetrahedron, 2010, 66, 344-349.

16 G. N. Roviello, M. Moccia, R. Sapio, M. Valente, E. M. Bucci, M. Castiglione, C. Pedone, G. Perretta, E. Benedetti and D. Musumeci, Synthesis, characterization and hybridization studies of new nucleo-gamma-peptides based on diaminobutyric acid, J. Pept. Sci., 2006, 12, 829-835.

17 G. N. Roviello, D. Musumeci, M. Moccia, M. Castiglione, R. Sapio, M. Valente, E. M. Bucci, G. Perretta and C. Pedone, dabPNA: design, synthesis, and DNA binding studies, Nucleosides, Nucleotides Nucleic Acids, 2007, 26, 1307-1310.
18 G. N. Roviello, D. Musumeci, C. Pedone and E. M. Bucci, Synthesis, characterization and hybridization studies of an alternate nucleo epsilon/gamma-peptide: complexes formation with natural nucleic acids, Amino Acids, 2010, 38, 103-111.

19 P. L. Scognamiglio, C. Di Natale, M. Leone, M. Poletto, L. Vitagliano, G. Tell and D. Marasco, G-quadruplex DNA recognition by nucleophosmin: new insights from protein dissection, Biochim. Biophys. Acta, 2014, 1840, 2050-2059.

20 M. Poletto, M. C. Malfatti, D. Dorjsuren, P. L. Scognamiglio, D. Marasco, C. Vascotto, A. Jadhav, D. J. Maloney, D. M. Wilson 3rd, A. Simeonov and G. Tell, Inhibitors of the apurinic/apyrimidinic endonuclease 1 (APE1)/ nucleophosmin (NPM1) interaction that display anti-tumor properties, Mol. Carcinog., 2015, DOI: 10.1002/mc.22313.

21 S. L. Topalian, S. Kaneko, M. I. Gonzales, G. L. Bond, Y. Ward and J. L. Manley, Identification and functional characterization of neo-poly(A) polymerase, an RNA processing enzyme overexpressed in human tumors, Mol. Cell. Biol., 2001, 21, 5614-5623.

22 G. Song and J. Ren, Recognition and regulation of unique nucleic acid structures by small molecules, Chem. Commun., 2010, 46, 7283-7294.

23 G. N. Roviello, D. Musumeci, V. Roviello, M. Pirtskhalava, A. Egoyan and M. Mirtskhulava, Natural and artificial binders of polyriboadenylic acid and their effect on RNA structure, Beilstein J. Nanotechnol., 2015, 6, 1338-1347.

24 L. Moggio, A. Romanelli, R. Gambari, N. Bianchi, M. Borgatti, E. Fabbri, I. Mancini, B. di Blasio, C. Pedone and A. Messere, Alternate PNA-DNA chimeras (PNADNA)(n): synthesis, binding properties and biological activity, Biopolymers, 2007, 88, 815-822.

25 G. N. Roviello, V. Roviello, D. Musumeci and C. Pedone, Synthesis of a novel benzodifuran derivative and its molecular recognition of poly rA RNA, Biol. Chem., 2013, 394, 1235-1239.

26 G. N. Roviello, D. Musumeci, C. D'Alessandro and C. Pedone, Binding ability of a thymine-functionalized oligolysine towards nucleic acids, Bioorg. Med. Chem., 2014, 22, 9971002.

27 G. N. Roviello, D. Musumeci and V. Roviello, Cationic peptides as RNA compaction agents: A study on the polyA compaction activity of a linear alpha,epsilon-oligo-l-lysine, Int. J. Pharm., 2015, 485, 244-248.

28 A. S. Saghyan, H. M. Simonyan, S. G. Petrosyan, A. V. Geolchanyan, G. N. Roviello, D. Musumeci and V. Roviello, Thiophenyl-substituted triazolyl-thione Lalanine: asymmetric synthesis, aggregation and biological properties, Amino Acids, 2014, 46, 2325-2332.

29 G. N. Roviello, S. Di Gaetano, D. Capasso, S. Franco, C. Crescenzo, E. M. Bucci and C. Pedone, RNA-binding and viral reverse transcriptase inhibitory activity of a novel cationic diamino acid-based peptide, J. Med. Chem., 2011, 54, 2095-2101.

30 G. N. Roviello, S. Di Gaetano, D. Capasso, A. Cesarani, E. M. Bucci and C. Pedone, Synthesis, spectroscopic studies and biological activity of a novel nucleopeptide 
with Moloney murine leukemia virus reverse transcriptase inhibitory activity, Amino Acids, 2010, 38, 1489-1496.

31 G. N. Roviello, D. Musumeci, C. D'Alessandro and C. Pedone, Synthesis of a thymine-functionalized nucleoamino acid for the solid phase assembly of cationic nucleopeptides, Amino Acids, 2013, 45, 779-784.

32 A. Guaragna, G. N. Roviello, S. D'Errico, C. Paolella, G. Palumbo and D. D'Alonzo, Solid phase synthesis of a novel folate-conjugated 5-aminolevulinic acid methyl ester based photosensitizer for selective photodynamic therapy, Tetrahedron Lett., 2015, 56, 775-778.

33 L. T. Nguyen, J. K. Chau, N. A. Perry, L. de Boer, S. A. Zaat and H. J. Vogel, Serum stabilities of short tryptophan- and arginine-rich antimicrobial peptide analogs, PLoS One, 2010, 5, e12684, DOI: 10.1371/journal.pone.0012684.

34 P. E. Nielsen, M. Egholm, R. H. Berg and O. Buchardt, Sequence-selective recognition of DNA by strand displacement with a thymine-substituted polyamide, Science, 1991, 254, 1497-1500.

35 G. N. Roviello, G. Roviello, D. Musumeci, E. M. Bucci and C. Pedone, Dakin-West reaction on 1-thyminyl acetic acid for the synthesis of 1,3-bis(1-thyminyl)-2-propanone, a heteroaromatic compound with nucleopeptide-binding properties, Amino Acids, 2012, 43, 1615-1623.

36 G. N. Roviello, G. Roviello, D. Musumeci, D. Capasso, S. Di Gaetano, M. Costanzo and C. Pedone, Synthesis and supramolecular assembly of 1,3-bis(10-uracilyl)-2propanone, RSC Adv., 2014, 4, 28691-28698.

37 C. Vicidomini, M. R. Panico, A. Greco, S. Gargiulo, A. R. Coda, A. Zannetti, M. Gramanzini, G. N. Roviello, M. Quarantelli, B. Alfano, B. Tavitian, F. Dollé, M. Salvatore, A. Brunetti and S. Pappatà, In vivo imaging and characterization of [(18)F]DPA-714, a potential new TSPO ligand, in mouse brain and peripheral tissues using small-animal PET, Nucl. Med. Biol., 2015, 42, 309-316.

38 D. Musumeci, C. Riccardi and D. Montesarchio, GQuadruplex Forming Oligonucleotides as Anti-HIV Agents, Molecules, 2015, 20, 17511-322015.

39 L. Simeone, D. Milano, L. De Napoli, C. Irace, A. Di Pascale, M. Boccalon, P. Tecilla and D. Montesarchio, Design, Synthesis and Characterisation of Guanosine-Based Amphiphiles, Chem.-Eur. J., 2011, 17, 13854-13865. 